


\title{
Acidentais ocidentes e a surdez de Aristóteles: para uma Geografia da Filosofia
}

Autor(es): $\quad$ Carvalho, Mário Santiago de

Publicado por: Faculdade de Letras da Universidade de Coimbra

URL persistente:

URI:http://hdl.handle.net/10316.2/39973

DOI:

DOl:https://doi.org/10.14195/0870-4112_2_6

Accessed : $\quad$ 26-Apr-2023 10:10:52

A navegação consulta e descarregamento dos títulos inseridos nas Bibliotecas Digitais UC Digitalis, UC Pombalina e UC Impactum, pressupõem a aceitação plena e sem reservas dos Termos e Condições de Uso destas Bibliotecas Digitais, disponíveis em https://digitalis.uc.pt/pt-pt/termos.

Conforme exposto nos referidos Termos e Condições de Uso, o descarregamento de títulos de acesso restrito requer uma licença válida de autorização devendo o utilizador aceder ao(s) documento(s) a partir de um endereço de IP da instituição detentora da supramencionada licença.

Ao utilizador é apenas permitido o descarregamento para uso pessoal, pelo que o emprego do(s) título(s) descarregado(s) para outro fim, designadamente comercial, carece de autorização do respetivo autor ou editor da obra.

Na medida em que todas as obras da UC Digitalis se encontram protegidas pelo Código do Direito de Autor e Direitos Conexos e demais legislação aplicável, toda a cópia, parcial ou total, deste documento, nos casos em que é legalmente admitida, deverá conter ou fazer-se acompanhar por este aviso.




REVISTA DA FACULDADE DE LETRAS U N I VERS I A D E D E C O I M B RA 


\section{Már io Sant iago de Car val ho}

Universidade de Coimbra

\section{Acident ais ocident es e a sur dez de Ar ist ót el es Par a uma Geografia da Fil osofia*}

«Philosophiquement, le monde medieval n'a pas de centre»

(A. de Libera)

«ni seuil ni deuil»

(J. Derrida)

\section{Abstract:}

This paper deals with the theme of 'translatio studiorum in spatio', thus proposing a shift from a history of philosophy to a geography of philosophy. This is then applied to two authors (Orosius and Martin of Braga) and to three subjects: tolerance (mainly Llull), contingency (mainly Ibn Sina) and incoherence (mainly Averroes).

A geografia da filosofia ainda aguarda o seu Hegel* 1. E isto por que a filosofia ocidental - não discutiremos quer por quanto tempo mais se pode ou se deve manter esta restrição disciplinar quer se a filosofia não é simplesmente ocidental - é também coisa geográfica. Caminhos aci dentais de ocidentalização. Se numa parte substancial se pode conjugar a construção do que chamamos Ocidente com a derivação geopolítica da filosofía, o Ocidente que convencionamos tem as suas raízes na Ásia e em África ${ }^{2}$. Esta percepção geográfica, impossível, como diremos, sem a

Adaptam-se aqui duas das lições que integraram o curso que regemos no Centro Universitário do Luxemburgo (vd. Centre Universitaire du Luxembourg, Département des Lettres et des Sciences Humaines. Structures et Programmes, Année académique 2002$-2003,75)$.

1 Seria evidentemente um erro pressupor aqui que foi Hegel o criador da História da Filosofia (vd. por isso, Ch. Giolito, «L'histoire de la Philosophie» in Enciclopédie Philosophique Universelle, vol. IV: Le Discours Philosophique (Paris 1998) 1604-12). No entanto, porque a radicalidade interpretativa da sua obra no sector da filosofia da história como matriz de uma história da filosofia criativa sobressai como um marco, justifica-se a sinédoque. Para o período histórico que nos interessa, vd. J. Inglis, Spheres of Philosophical Inquiry and the Historiography of Medieval Philosophy (Leiden 1998).

2 Cf. R. Garaudy, Para um Diálogo das Civilizações. O Ocidente é um acidente, trad. (Lisboa 1977) 18.

\section{Faculdade de Letras Universidade de Coimbra}


matriz estoica e a deriva católica, contrasta com a surdez de Aristóteles relativa aos filósofos nus; com efeito, ao descobrir os gimnosofistas na índia o exército de Alexandre (a geografia é-lhe praticamente contempo rânea $^{3}$ ) ficou a saber como a meditação e o exercício ascético da vontade possibilitavam o domínio de determinadas funções vitais do corpo (a res piração, o ritmo cardíaco, etc.), mas é espantoso que perante esta impres sionante descoberta o Filósofo de Estagira continue a subtrair a alma vegetativa ao domínio da razão ${ }^{4}$.

Se é certo que o idioma originário da filosofia é o grego (mas de que grego falamos nós em cada filosofar?), o Ocidente não é menos radicalmente latino, não obstante a deriva arábica da filosofia (falsafa). Este ponto é evidente na sinédoque latina de Jorge Luis Borges, no caso no inevitável sector da literatura ${ }^{5}$. Ainda hoje um vasto espaço geográfico humano e cultural filosofa numa idiomática neolatina e, mesmo quando isso nem sempre sucede, como no espaço linguístico anglo-saxónico, tem sido perenemente greco-latina a sua mais radical conceptualização ${ }^{6}$. Conhecemos poucos exemplos como o do neerlandês que ousou invocar um vocábulo, wijsbegeerte, aliás mantendo a legitimidade semântica do velho e mais severo filosofie. Não é preciso observar que o termo grego chegou até nós por transliteração latina, philosophia, fácil estratégia (ape sar de problemáticamente carregada haja em vista as discussões de um Heidegger ou de um Gilson) de que nem sequer logrou escapar o lexema falsafa.

Sendo o islamismo também uma religião transgeográfica, a sua projecção do espaço centrou-se nas estradas, geodesia esta mais alheia ao cristianismo que desde cedo escolheu o mar $^{7}$. Entre as fontes da sua teolo gia (kalam) e filosofia (falsafa) não se pode só considerar o Alcorão, Hadith (coleção dos ditos do Profeta) ou os dizeres dos imans no espaço xiita $^{8}$. Na filosofia, sobretudo, há ainda que chamar à colação um complexo e diversificado fundo helénico, sírio, indiano e persa. Quero

3 Cf. A Bonnard, A Civilização Grega, trad. (Lisboa 1980) 645-48.

4 Sobre a relação de Alexandre com os gimnosofistas, vd. e.a. Plutarco, Vite Paralelle: Alessandro c. 64, ed. D. Magnino (Milano 1994) 187; cf. Aristóteles, Eth.Nic. 1 13,1102 b.

5 Cf. J.L. Borges «Literatura, latinidade?» in G. Duby (dir.), A Civilização Latina. Dos Tempos Antigos ao Mundo Moderno, trad. (Lisboa 1989) 49-60.

$\wedge^{\wedge}$ Cf. e.g. J.-M. Fontanier, Le vocabulaire latin de la Philosophie (Paris 2002).

7 J. Le Goff, Em busca da Idade Média. Com a colaboração de J.-M. De Montremy, trad. (Lisboa 2004) 123.

8 Cf. A. Merad, La tradition musulmane (Paris 2001 ) 30 sq. 
dizer: todo um 'ethos' pré-islâmico indiano-persa, sem dúvida alguma marcante daquela dimensão intelectual que depois de Avicena se vem chamando «a filosofia oriental» adiante caracterizada. Mais ainda (e para aumentar a dificuldade): se houve uma transmissão islâmica à filosofia latina (século XII em diante) também houve uma transmissão cristã (séc. VI em diante) aos filósofos (falasifa, sing.: faylasuf) islâmicos. Caso significativo é o do devir do Aristóteles Sírio, tão importante na teologia cristã, mas que é anterior ao Aristóteles Árabe. A leitura do importante Catálogo (Kitab al-fihrist) do livreiro de Bagdade, Ibn al-Nadim (+ 990), é bem reveladora de uma helenofilia arábica sem fronteiras. Ao lado de Proclo ou Porfirio também lá aparecem títulos dos cristãos João Filópono e Gregorio de Nissa9 ${ }^{9}$. Dado importante, ainda, a emigração, também oriental, para Harran (Pérsia) dos filósofos pagãos expulsos da Academia por Justiniano (529), depressa tornada um centro intelectual cosmopolita acolhedor das ciências médicas, da poliglossia e das traduções, e também dos intelectuais cristãos (mormente nestorianos), todos juntos seguindo uma 'koiné' neoplatónica ocidental no Oriente. Caberia por isso distinguir entre um neoplatonismo oriental (o de Numénio) e um ocidental (Proclo), sendo aquele, mais do que este, marcado simultaneamente pela influência do monoteísmo e do dualismo iraniano, quer dizer, «aberto ao pensa mento grego, ao pensamento persa e às religiões monoteístas, incluindo o cristianismo, o islamismo e a religião sabeíta» ${ }^{10}$. A Síria e o Iraque são o ocidente de Harran em Bagdade, onde ainda encontramos cristãos sírios a combaterem as propostas religiosas dos harranitas, para o que se terão servido tecnicamente mais das ciências e da lógica aristotélicas, enquanto os intelectuais harranitas ensinavam aos islâmicos uma leitura de Aristó teles ao serviço de uma racionalidade metafísica de recorte oriental. Tais itinerários, sejam de instrumentalização sejam de harmonização acabarão por explicar por que é que Alfarabi (870-950) redige um Livro da conci liação entre o divino Platão e o sábio Aristóteles ${ }^{\wedge}$. Como contraponto

9 Cf. Ibn al-Nadim, The Fihrist of al-Nadim, trans. B. Dodge, 2 vols. (New York 1970). Não se cuidará aqui de uma outra vertente importante, a relativa à expressão cristã em árabe, vd. S.H. Griffith, The Beginnings of Christian Theology in Arabic. Muslim Christian Encounters in the Early Islamic Period (Aldershot 2002).

M.A. Yabri, Legado filosófico árabe: Alfarabi, Avicena, Averroes, Abenjaldún. Lecturas contemporáneas, trad. (Toledo 2001) 175. Fique dito que somos dos que propõem que se fale numa dupla tradição ocidental neoplatónica, a de Proclo e a de Porfirio.

$\wedge$ Cf. Alfarabi's Philosophy of Plato and Aristotle, trans. M. Mahdi (New York 1962); Al-Farabi, Libro de la concordanda entre el divino Platón y el sabio Aristóteles, trad., prólogo y notas de M. Alonso in Pensamiento 25 (Madrid 1969) 21-70. 
temos a ideia de «incoerência», onde se destacou a parte 'mais ocidental da filosofia (Averróis e Moisés Maimónides), legando desta maneira ao Ocidente o rosto perdido (grego) do ocidente, no que virá a ser a possibilitação do que aqui nos atreveremos a chamar o pesadelo de Tocqueville (1840): a profecia de que os Estados Unidos antecipam um estilo de vida que permite à Europa ver ao espelho o seu próprio futuro ${ }^{12}$.

No que se segue, recorrendo desigualmente a dois espaços, cuidaremos, primeiro (II), em contribuir para aumentar o grau de comple xidade inerente a uma transmissão que não é monocêntrica, mas preen chida de itinerários polidireccionais. Orósio e Martinho de Braga ou de Dume servem-nos para descentrar qualquer «projecção de Mercator» que inevitavelmente governa as Histórias da Filosofia. Motiva-nos a experiên cia ingénua de Baquiário (séc. IV) quando reclama não ser julgado em nome da geografia, mas das suas ideias sem se aperceber quanto aquela pode determinar estas ${ }^{13}$. Isto poderia ser visto como um contributo para o tema da translatio studiorum (in spatio, frisamos) com o qual se costuma perceber o advento da latinidade filosófica e aquela que seria eventual mente a sua primeira erupção medieval, a chamada renascença carolíngia marcada pelo inteligente desiderato de edificar uma nova Atenas, embora no quadro de uma velha Roma com o apoio declarado de uma velha Jeru salém e mediante a intervenção de uma velha Bizâncio. Tenha-se presente a oferta das relíquias e dos manuscritos de Dionisio à abadia parisiense de São Dinis, o facto imponente de João Escoto Eriúgena estar ligado à des coberta ocidental daquele monge sírio, tomado famoso sob uma capa de falsário, e a inteligente percepção da dinastia carolíngia ao concitar o concurso do filósofo para a sua pretensão imperial ${ }^{14}$. Estamos no século IX da era Cristã e, por isso, alguma água corria já debaixo das pontes do nóvel império romano do Ocidente. Não obstante o seu inegável valor para pensar a história da filosofia, a ideia da translação dos estudos esteve ligada à da translação do Império como instrumento de propaganda ocidental cristã. Alain de Libera pleiteou por uma pluralidade de transla-

12 Cf. A. de Tocqueville, De la démocratie en Amérique, ed. E. Nola. Tome II (Paris 1990); para uma ilustração e aplicação positiva e actualissima, do programa de Tocqueville, vd. V. Soromenho-Marques, A Revolução Federal. Filosofia política e debate constitucional na fundação dos E. U.A. (Lisboa 2002) 9-30 e 177-79.

13 Cf. P.G.A. de Sousa, Patrología Galaico-Lusitana (Lisboa $\left.{ }^{2} 2001\right) 34$.

14 Cf. Pseudo-Dionísio Areopagita, Teologia Mística. Versão do grego e estudo complementar de M.S.de Carvalho, in Mediaevalia Textos e Estudos 10 (Porto 1996) 27-34. 
ções chegando mesmo a evocar alguns itinerários ${ }^{15}$. Contudo, ainda não foi dita a última palavra sobre os itinerários e a sua cartografia e pode-se dizer que a alegada esterilidade filosófica do Ocidente só se justifica se confundirmos, numa projecção mental de Mercator, a loxodrómia com a ortodrómia ${ }^{16}$. Tendo isto em vista, essa primeira estratégia permite-nos ilustrar uma incoação, ortodrómica, das ideias quer da mundanização do tempo (Orósio) quer do relativismo espacial e cultural (Martinho).

Dado que a geografia não é só «humana» mas também «física», passaremos, depois (III), de modo mais abreviado embora, res pectivamente para um tópico e uma metáfora capitais nas filosofias islâ micas. Ambas, «contingência» e «incoerência», se nos afiguram adequa das para perceber fenómenos antagónicos de intussuscepção (termo que opomos ao de justaposição) inerentes ao vasto complexo das relações filosofia/religião que está longe de coincidir com a diferença Ocidente/Oriente ${ }^{17}$. Na obra supracitada Alfarabi começa exactamente por evidenciar os motivos de discrepância na interpretação dos dois gregos referidos no título da obra: criação e eternidade do mundo, alma, inte lecto, recompensa e castigo, além de outras questões políticas, éticas e lógicas. Ora, no seio do tópico da contingência, ocasionado nos quadros da controvérsia sobre a criação e a eternidade do mundo, graças ao pro longamento de uma profunda intuição de Alfarabi, separar para unir, Avicena gera uma região conceptual só possível pela assunção de estrutu ras triádicas não meramente justapostas. Quanto à incoerência (ou incomensurabilidade, num léxico hodierno), ela foi explicitamente vivida na crítica que o filósofo cordovês Averróis dirigiu (Tahafut al-tahafut) ao

15 A. de Libera, La philosophie médiévale (Paris 1993) 7: «Il y a plusiers translationes studiorum aux confines de l'Antiquité et du Moyen Age: l'une se fait d'Athènes en Perse et de Perse à Harrân (à moins que ces deux transferts n'en fassent qu'un), d'autres se font d'Alexandrie aux monastères syriens du Vile et du Ville siècle, un troisième mouvement s'effectue par la culture syriaque vers la culture arabe, d'Alexandrie à Bagdad. Ces mouvements occupent tout le haut Moyen Age: ils suffisent à encadrer et structurer une histoire. Toutes les durées, pour autant, ne se ressemblent pas. A la même époque l'Occident chrétien est philosophiquement sterile. Il ne sortira de son long sommeil qu'avec une nouvelle translatio allant de Bagdad à Cordue, puis à Tolède, autrement dit: de l'Orient musulman à l'Occident musulman, puis, de là, à l'Occident chrétien.»

$\wedge$ Fique dito que «loxodrómia» designa a linha de azimute constante representada na carta por uma linha recta que facilita o cálculo, mas não representa a distancia mais curta entre dois pontos, cf. J. A Torres, «A matemática $\mathrm{e}$ a forma de ver o mundo» in M.P.S.de Oliveira (coord.), Teias Matemáticas (Lisboa Coimbra 2004) 175. Carvalho, Estudos sobre Alvaro Pais e outros Franciscanos (séculos XJII-XV) (Lisboa 2001) 30 . 


\section{Mário Santiago de Carvalho}

magistral libelo de Algazel (+ 1ili), precisamente intitulado A Incoerên cia [ou Destruição] dos filósofos ( Tahafut al-falasifa). O género algazélico galgou fronteiras e idiomas: nos finais do século XIII o filósofo e teólogo Egídio Romano ainda haverá de escrever um trabalho sobre $\boldsymbol{O} \boldsymbol{s}$ Erros dos Filósofos \{De erroribus philosophorum), concebido na e justi ficado pela atmosfera da recepção da filosofia de Averróis pelos Latinos. Desejaríamos evidenciar, então, que os dois tópicos apontados abrem outros tantos caminhos de extrema ocidentalização. Um dos vários dile mas que miramos é porém complexo mas urgente: frente à ameaça geo política do terrorismo camuflado de islamismo a coincidência entre o que aqui nos atrevemos a chamar a surdez de Aristóteles e o pesadelo de Tocqueville poderia quiçá encontrar no exemplo de Averróis/Maimónides um ensinamento a ter em conta. Tomás de Aquino também herdou destes dois pensadores num sentido que aponta para além deles mesmos, de modo aberto e incompleto ${ }^{18} 19$.

A partir do século XIX sobretudo falou-se de «história da filo sofia» com o óbvio privilégio do vector tempo. Há contudo uma outra forma de devir, relativa ao espaço. Uma indagação no âmbito deste vector, desde os seus primórdios descritivos militares até à situação actual de reorientação epistemológica corresponde ao procedimento geográfico 19. Se a história privilegia o tempo e o seu horizonte é cosmo-psicológico, a geografia, que privilegia o espaço, tem nas figuras polissémicas do poder a sua expressão e horizonte mais fortes. Esta «revolução copemicana» (justifiquemos a alusão pelo facto de Kant ter sido professor de geografia) é perfeitamente adequada para descrever, para cartografar, momentos de maior crise na translação, na transliteração, filosófica. Há um tríptico geopolítico, aliás difícil de cartografar, na raiz desta crise: a filosofia, o semitismo (judaico-cristão), as tradições bárbaras e este ultimo sistema de representações tem sido evidentemente o mais desprezado ${ }^{20}$.

Diversamente, se quiséssemos, o paradigma da história poderia ser evidenciado pela metáfora teleológica e dinâmica exitus/reditus que

18 Cf. A. MacIntyre, Tres versiones rivales de la ética. Enciclopedia, Genealogía y Tradición, trad. (Madrid 1992) 164.

19 Cf. Y. Lacoste, «A Geografía» in F. Châtelet (dir.), Historia da Filosofia: A Filosofia das Ciências Sociais (de I860 aos nossos dias), trad. (Lisboa 1977) 243.

20 A.I. Gurevitch, As Categorias da Cultura Medieval, trad. (Lisboa 1990) 35; A. MacIntyre, After Virtue. A Study in Moral Theory, Notre Dame²1984, 166.

Faculdade de Letras i Universidade de Coimbra 
Eriúgena foi o primeiro a aplicar na fronteira trans-idiomática ${ }^{21}$. Já muito antes, a paradigmática peregrinação de Egéria traduzia a tensão perma nente para superar o plano do espaço no do tempo ${ }^{22}$ e nem sequer a Nave gação de São Brandão escapa a esta tentação escatológica ${ }^{23}$. Talvez ela se deva à predominância do relato genesíaco na forma mental judaicocristã, aspecto este bem presente, v.g., na Cosmographia, um dos mais notáveis tratados geográficos medievais, que põe na base do trajecto de 'Ethicus' a descrição cosmológica da Criação ${ }^{24}$.

Sem remontarmos na invenção genealógica «original» que da Grande Grécia nos obrigaria a viajar quiçá até à pátria da História, a inquietante e efervescente Suméria, narrativa aliás com o seu quê de con jectural e de projeção arquetipal ${ }^{25}$, a verdade é que o avanço lento e pro gressivo do viajante, antes de alcançar, como filósofo, as praias do Pací fico só nos alvores do século XX, teve de trilhar terrenos culturais de miscigenação cuja primeira investida mais impressionante foi a da pres são migratória bárbara do Norte auferindo de um declínio da matriz grega e da hipertrofia das religiões, consolidando-se na diversificada bacia do Mediterrâneo. Porque esta é uma história do poder vertida sob o tópico da verdade elucidemos preliminarmente uma consequência de uma «revolu ção copernicana» possível.

\section{Tolerâncias}

É estranho, mas é verdade; parece ser afinal o destino de toda a religião. Os pensadores entendiam com facilidade que a Verdade era infixável, que ninguém a detinha, mas, postos perante a situação inter-religiosa, resultava indiscutível que uma das religiões reveladas deveria ser sempre a detentora da verdade. O medievalista Umberto Eco (O Nome da Rosa) pôs na boca ficcional de Adso de Melk, a palavra do romântico alemão Gotthold Lessing (Nathan der Weise, 1779), a qual, por sua vez,

71

M.S.de Carvalho, A Síntese Frágil. Uma introdução à Filosofia (da Patrística aos Conimbricenses) (Lisboa 2002) 44-45.

77 Cf. Egéria. Viagem do Ocidente à Terra Santa, no Séc. IV. Ed. de A.B. Mariano e A. A. Nascimento (Lisboa 1998).

${ }^{2 \wedge}$ Cf. Navegação de S. Brandão nas fontes portuguesas medievais. Ed. crítica de A.A. Nascimento (Lisboa 1998).

${ }^{24}$ Cf M. Lapidge, «Il secolo VIII» in C. Leonardi (a cura di), Letteratura Latina Medievale (Firenze 2003) 58.

2 ${ }^{*}$ J.N. Carreira, A Filosofia antes dos Gregos, trad. (Lisboa 1994). 


\section{Mário Santiago de Carvalho}

havia sido consagrada numa velha perplexidade, há muito levada ao texto por Boccaccio (Decameron I 3), na parábola dos três anéis (1349/50):

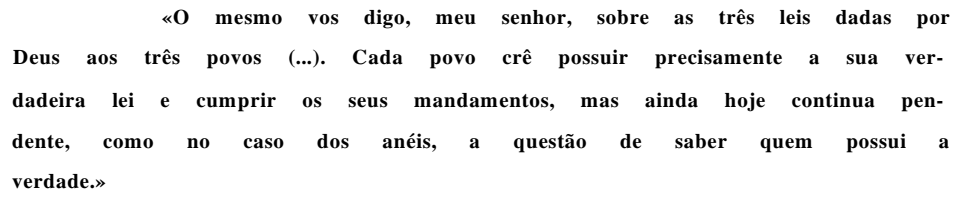

Três religiões, judaica, cristã e islâmica, conviviam e degladiavam-se mutuamente no vasto espaço geográfico europeu. Hoje, menos confiantes na verdade, empós o o que prefiro designar como o quádruplo magistério da suspeita (Espinosa, Nietzsche, Marx, Feud), pensamos o problema no quadro da tolerância. O princípio porém não é novo dado que, se o mundo cristão greco-latino nunca foi realmente capaz de conce ber uma teoria da tolerância, foi contudo capaz, nos campos de fronteira, de tolerar quase tudo ${ }^{26}$. Mas de que 'tolerância' falamos nós em cada caso? Seja-nos permitido citar o austero Alexandre Herculano (O Monge de Cister), descrevendo em tom castiço a organização urbana conviven cia! das três religiões ${ }^{27}$ :

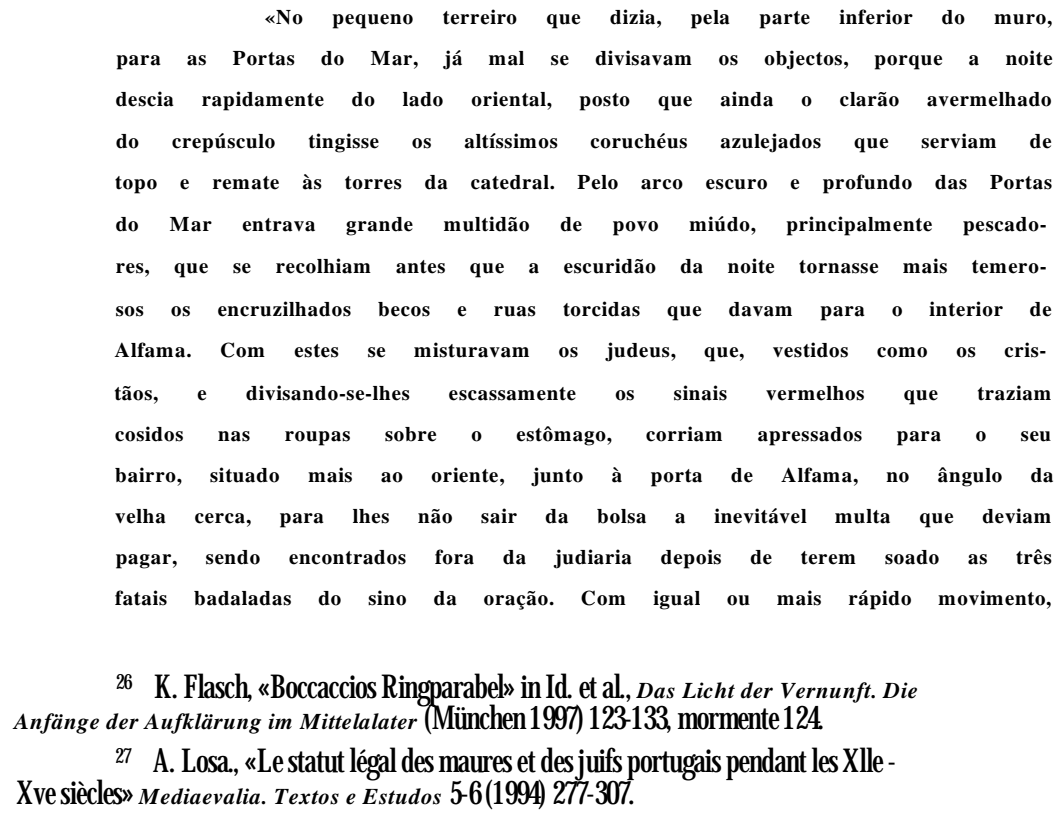

26 K. Flasch, «Boccaccios Ringparabel» in Id. et al., Das Licht der Vernunft. Die Anfänge der Aufklärung im Mittelalater (München 1997) 123-133, mormente 124.

27 A. Losa., «Le statut légal des maur es et des juifs portugais pendant les Xlle Xve siècles» Mediaevalia. Textos e Estudos 5-6(1994) 277-307. 


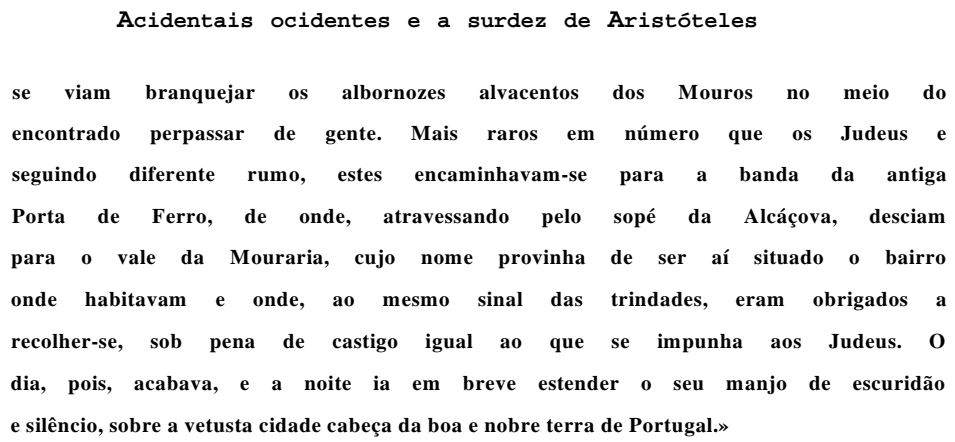

Ao tornar-se religião de Estado o Cristianismo forçou a teologia pagã a constituir-se como ciência e como teologia platónica (com Proclo). Este gesto levou também a teologia cristã a buscar para si os elementos daquela constituição integrando-os numa construção teológica científica cristã (Pseudo-Dionísio Areo pagita $)^{28}$. Quando no século IV as expressões grega e latina do Império se sepa ram, para jamais se encontrarem, apesar do episódio ambíguo do Renascimento, as práticas patrísticas são já porém diversas. Questões de sócio- ou geolinguística que não nos fazem estranhar uma proposta como a de Amor Ruibal (1869-1930), distinguindo uma Patrística Grega, mais relacional e personalista, de uma Patrís tica Latina, porventura de carácter mais essencialista e abstracto ${ }^{29}$.

O impropriamente chamado Helenismo foi sem sombra de dúvida um momento importantíssimo de crise na transformação do modo como se fazia filosofia e como ela era entendia. Não que não houvesse sinais, heranças e filões nesse sentido (a denominada «revolução socrá tica» e o 'déjà vu' suscitado pelo socratismo entre os Cristãos é disso um

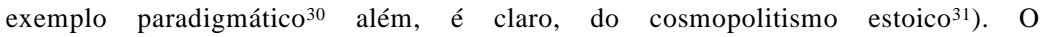
entendimento da filosofia como arte de vida (ars uitaé) preconizado pelas escolas helenísticas (estoicos, epicuristas e pirronistas) traduzia uma car tografia partilhada. Citando Jean Leclercq, Pierre Hadot fez seu o seguinte paralelo: « $\mathrm{Na}$ Idade Média monástica, tal como na Antigui dade, philosophia já não designa uma teoria ou uma maneira de conhecer, mas uma sabedoria vivida, uma maneira de viver segundo a razão', quer dizer, segundo o Logos. ${ }^{32} \gg$ A ventura e virtualidades do modelo filo-justi-

28 H.D. Saffrey, «Les débuts de la théologie comme science (IIIle-VIe. siècle)» Revue des sciences philosophiques et théologiques 80 (1996) 201-20.

29 Sobre 0 autor (1869-1930) vd. C.A. Baliñas, El pensamiento de Amor Ruibal (Madrid 1968).

30 Cf. E. Gilson, L Esprit de la Philosophie Médiévale (Paris 1944) c. XI, 21.

31 M.S.de Carvalho, o Problema da Habitação (Lisboa 2002) 13-15.

32 P. Hadot, Qu'est-ce que la philosophie antique? (Paris 1995) 360. 


\section{Mário Santiago de Carvalho}

nista do logos encarnam uma forma espacial quando estoicismo e catoli cismo passam a coordenar-se, o que sucede com a gentilização da mensa gem cristã (Pedro e Paulo). Que esta expansão comporta uma componente geográfica óbvia testemunha-o a dilatação moderna do mundo com a consequente requisição da imaginação, dos temas da meditatio mortis (et vitae), mas também do laxismo e do probabilismo ${ }^{33}$.

O Helenismo viu as ameaças gnósticas e o Cristianismo de ori gem judaica. Quando o egípcio Plotino, o último dos grandes filósofos de expressão helénica, intervém, a filosofia grega está estoicamente habili tada a pensar a(s) religião(ões) e os seus desafios (o advérbio é aqui usado no seu sentido literal, stoa, concernente à arquitectura aberta como repre sentação cosmopolita). Pense-se na teoria da génese do Universo por emanação do Uno que tanto irá dar que pensar à crítica dos filósofos por Algazel quando demonstra ser Deus a causa eficiente ou agente do cos $\operatorname{mos}^{34}$. O judeu Filon já havia demonstrado o preço a pagar pela cosmopolitização da filosofia, em Alexandria, submetendo uma herança religiosa literária ao crivo da interpretação filosófica assim inventando camadas de sentido nos textos patrimoniais. A maior parte dos chamados Padres da Igreja (em Alexandria, na Capadócia, em África ou até mesmo em Antioquia) terão feito o mesmo, permitindo, com esse gesto, a erecção de uma teologia que encontrará a sua expressão científica de rigor, mais tarde, no século XIII, no aristotelismo ${ }^{35}$. Este episódio, apesar de tudo breve e situado, não pode ser sobrestimado, mas ele revelou horizontes inesperados à velha e pioneira estratégia alegorista de leitura homérica . Outros modelos foram propostos, pelo que de seguida recordaremos dois deles.

Antes da fractura que cinde a catolicidade foi possível chegar-se ao século XV (A Paz da Fé de Nicolau de Cusa data de 1453) e assis tir a uma reflexão irenista, feita à moda de diálogo com o Verbo, com Pedro e com Paulo, de representantes de algumas religiões e tradições culturais da época, embora numa actualização das «filosofias que mais se aproximaram da verdade da fé cristã», segundo o dizer matricial de Agostinho CDe Civ. Dei VIII, 9). O Grego, o Italiano, o Árabe, o índio, o

33 Cf. R. Bodei, Géométrie des passions. Peur, espoir, bonheur: de la philosophie à l'usage politique, trad. (Paris 1997) 55; P.Hadot, Exercices spirituels et philosophie antique (Paris 1987).

34 Cf. J. Puig Montada, «Averroes, y la crítica de Avicena», Revista Española de Filosofia Medieval 10 (2003) 127-138.

${ }^{33}$ M.S.de Carvalho, «A Idade Média filosófica terá sido aristotélica?», Humanitas 50 (1998) 489-508; M.-D. Chenu, La théologie comme science auXJIIe siècle (Paris 1957).

\section{Faculdade de Letras | Universidade de Coimbra}


Caldeu, o Judeu, o Cita, o Francês, o Persa, o Sírio, o Espanhol, o Turco, o Alemão, o Tártaro, o Arménio, o Boémio, o Inglês são os «sábios das nações» que vão sucessivamente intervindo nos dezanove pequenos capítulos em que aquela generosa obrinha se divide e cujo título genitivo (pax fidei), de acordo com o que sugere Agostinho em A Cidade de Deus (XIX, 11), deve ser interpretado à «semelhança do de 'visio Dei', simul taneamente um genitivo subjectivo e um genitivo objectivo»: o título refere a paz que a fé promove entre os Homens e «o reconhecimento da dinâmica inscrição e promoção da paz dentro da própria fé e das diversi ficadas crenças que são as suas múltiplas manifestações» ${ }^{36}$.

Distinta lógica da tolerância pretendera instaurar Raimundo Llull combatendo embora o dificilmente chamado «averroísmo latino». Do alcance desta frente latina temos testemunho, v.g., em Lisboa, no século XIV, por um mestre das escolas de Decretais, de seu nome Tomás Escoto $^{37}$ ou do médico e bispo da Guarda e Évora, Afonso Dinis ${ }^{38}$. No combate vincadamente diferencial e inclusivista de Llull, se não se perfila uma solução como aquela que no século XII Pedro Abelardo dramatizou (no Diálogo entre um Filósofo, um Judeu e um Cristão) ${ }^{39}$, também não se encontra uma lógica irenista como a de Nicolau de Cí́sa assente no prin cípio transssumptivo segundo o qual «os contrários se reunificam e os opostos se encontram numa vivência pessoal, comunitária e universal» ${ }^{40}$. De facto, toda a zelosa estratégia de Llull visa a conversão dos Sarrace nos, aliás na esteira proselitista da empresa de tradução do Alcorão por

Nicolau de Cusa. A Paz da Fé, seguida de Carta a João de Segovia. Trad, e introd. de J. M. André (Coimbra 2002). Sobre a obra, vd. a nossa recensão in Revista Filosófica de Coimbra 11 (2002) 473-76.

37 M.S. de Carvalho, Estudos sobre Álvaro Pais e Outros Franciscanos (Lisboa 2001)95-120.

38 M.S. de Carvalho, $O$ Problema... 128-136.

30 Petrus Abaelardus. Dialogus inter Philosophum, Iudaeum et Christianum, ed. R. Thomas (Stuttgart 1970); engl, transi, by P.J. Payer (Toronto 1979). Sobre este autor em português, vd. o nosso Lógica e Paixão. Abelardo e os Universais (Coimbra 2001) 11-41.

40

J.M. André, Sentido, simbolismo e interpretação no discurso filosófico de Nicolau de Cusa (Coimbra 1997) 778. A lógica transsumptiva, vale a pena recordá-lo, é o modelo teológico invocado na interpretação dos axiomas de Boécio a fím de vincar a heterogeneidade ontológica (a diferença teológica) sem romper com a sua inteligibilidade mediante a introdução de um termo médio escondido. Exemplificando (com as palavras do lógico e teólogo Gilberto de Poitiers): a metonimia metaléptica (transsumptiva denominatio) ou metalepse metonímica (denominativa trans sump ti o), que vai da essência do Bem ao ser das coisas que são e que são alguma coisa, faz com que não apenas elas sejam boas, mas ainda que sejam boas nelas mesmas todas as coisas que por essa metonimia são boas» (M.S.de Carvalho, $A$ Novidade do Mundo: Henrique de $G$ and $e$ a metafísica da temporalidade no século XIII (Lisboa 2001) 312-13 e 307-14 mais em geral). 


\section{Mário Santiago de Carvalho}

iniciativa de Pedro o Venerável (séc. XII), enquanto que a proposta cusana assenta na necessidade de uma lógica também alternativa ao velho tópico Aristóteles/Platão. A novidade lulista da equiparação, «um proce dimento lógico para concluir argumentos de conveniência sobre a reali dade finita, fundamentado basicamente na analogia do ser» ${ }^{41}$, comporta uma expressão vivencial cuja componente missionária, por definição, não pode deixar de ser geográfica. A tradução portuguesa da sua Vida Coetâ nea (que temos concluída) põe em evidência como uma conversão, no sentido radical da palavra, uma «iluminação», afina o pensamento. O que daí resulta será o reconhecimento das verdades contidas nas (várias) reli giões. E, como o demonstra a sua própria vida activa, de um ponto de vista filosófico esta atitude inclusivista não padece de ausência de diá logo. O que é significativo, aliás, é que o diálogo parta do inclusivismo assumido num plano filosófico e não teológico. Sem podermos entrar nas minúcias da Arte como prática filosófica universal e integral, bastará notar a preponderância da dúvida e do filosofar como soluções para dile mas que afectam hoje em dia o chamado «diálogo inter-religioso». «Para Lull, todo diálogo inter-religioso deve partir do que nos nossos dias se chamou o 'principle of charity' (Donald Davidson), isto é, a suposição de que aquilo que o outro nos quer dizer tem possivelmente um conteúdo proposicional verdadeiro. E este é só um lado da moeda, porque, ao mesmo tempo, também as crenças próprias, quando entram em diálogo, devem ser formuladas de maneira duvidosa, quer dizer, como verdades meramente possíveis, caso em que não estaríamos em condição de reco nhecer a possível verdade da religião do nosso interlocutor.» ${ }^{42}$

\section{II - Outros Mares}

No ano 410, debaixo do Sol de Agosto, sob o comando de Aladeo, os Visigodos invadem, pilham e destroem Roma, a cidade-Etema. Povos germanos (Godos), a sua cavalaria tinha infligido pesada derrota ao exército romano já em 378, em Andrinopla, no Império Romano do Oriente, enquanto fugiam dos Hunos, mas aquele século V

41 E. Jaulent., «A demonstração por equiparação de Raimundo Lúlio (Ramon Llull)» in L.A. De Boni (org.), Lógica e Linguagem na Idade Média (Porto Alegre 1995) 156.

42 A.Fidora, «Ramon Lull frente a la crítica actual al diálogo interreligioso: el arte luliana como propuesta para una 'filosofía de las religiones'», Revista Española de Filosofía Medieval 10 (2003) 233.

Faculdade de Letras | Universidade de Coimbra 
era o tempo da pressão dos bárbaros e da sua irreversível infiltração na Europa ocidental. A própria península Ibérica, nos confins do Ocidente, é vítima da invasão dos Vândalos, Suevos e Alanos. Noutro espaço geográ fico mais distante, o chamado Médio-Oriente (Belém), São Jerónimo (t 420) acolhe refugiados no seu mosteiro, tal como ao norte de África o bispo da cidade de Hipona, Agostinho, convida os seus diocesanos à cari dade do acolhimento dos infelizes romanos.

Santo Agostinho é um dues romano, outrora professor de retó rica, que ocupa uma sede episcopal, conjugando dessafeita a sua missão de pastor e de intelectual ${ }^{43}$. Neste duplo papel cabia-lhe responder a uma «teologia» imperial que via na recusa dos cristãos em prestarem culto aos deuses do Império e em se lhes submeterem, a causa da destruição da cidade-Etema. O bispo começa então a escrever A Cidade de Deus para isentar os cristãos da culpa que imediatamente se lhes atribuiu. A apolo gia era aliás, desde o século II um estilo literário filosófico consagrado cuja estratégia pragmática, dada a impossível (mercê do idioma) elevação da filosofia às suas expressões clássicas, visava a sua elevação por um efeito de classe: ser-se intelectual não é incompatível com ser-se cristão porque o cristianismo é uma teologia. É o tempo em que a filosofia se pode abrir a um bárbaro devir ${ }^{4 *}$.

Orósio

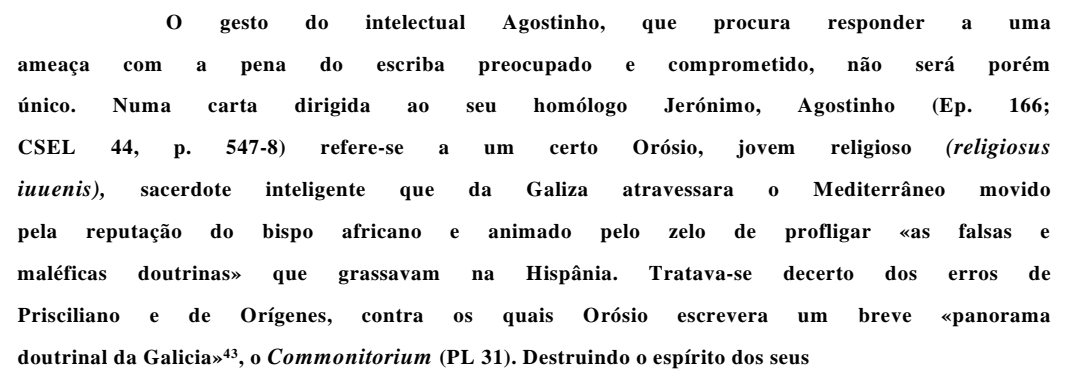

43 Cf. M.S.de Carvalho, «Presenças do Platonismo em Agostinho de Hipona (354-430). (Nos 1600 anos das Confissões)», Revista Filosófica de Coimbra 9 (2000) 289-307.

${ }^{44}$ M.S.de Carvalho, «Filosofia Bárbara (Considerações sobre a Patrística)», Itinerarium 41 (1995) 345 - 368.

43 P.G.A. de Sousa, Patrología... 51. Abrimos acima a possibilidade de confrontarmos Agostinho e Orígenes. Muitos aspectos unem estes dois enormes teólogos, mas tantos outros os dividem. E desde logo a diferença linguística, um latino que sabia púnico e um grego que sabia hebraico! Um cidadão de um império cada vez mais cristão frente a um cidadão de um império ainda pagão; um retórico existencial frente a um exegeta 
habitantes «ainda mais do que as espadas dos bárbaros», semelhantes ideias matavam os seus corpos. Convenhamos tratar-se de uma atmosfera corrente na Patrística, 0 apuramento da identidade (dogma) condicionada pela heresia (oportet hareses esse). Eis-nos em plena refrega do espírito, coisa de intelectuais comprometidos, isto, evidentemente, se não tiver sido antes 0 prosaico medo dos ataques dos Vândalos e Suevos abatendo-se sobre a sua Bracara Augusta, erigida a capital da Galaecia por Caracala, a explicar a emigração de Orósio.

De forma cenográfica embora, acabámos de identificar os intérpretes e de reconhecer o cenário da questão (a geografia não é só física também é humana). O Ocidente frente ao Oriente, o padre Orígenes de Alexandria, especialista na exegese alegórica e na filosofia grega, esta última causando-lhe erros teológicos vários; as eminências pardas Jeró nimo e Agostinho, pastores e intelectuais interventivos, aquele no campo da exegese e da tradução, este na exegese e na consolidação de uma teo logia católica; e reconhecemos, por fim, um jovem do norte, curioso, estudioso e preocupado com o clima mental e religioso da sua terra no extremo ocidental da Europa (priscilianismo, origenismo, pelagianismo) e, por isso, procurando impor uma identidade que se quer universal numa região multissecularmente pagã.

Geograficamente falando o caso ibérico exacerbava o barba rismo. Estamos já nos extremos ocidentais da filosofia (pelo menos assim será até ao século XVII na América do $\mathrm{Sul}^{46}$ e no XVIII mais ao norte com Jonathan Edwards) ${ }^{47}$. O priscilianismo, sobretudo, consistia numa expressão cultural popular, radicada na empatia céltica com os cultos astrais à beira dos cursos de água, bosques e montanhas. Autêntico paleocristianismo da região, esta heresia dominá-la-á pelo menos durante três séculos (IV-VI $)^{48}$. Por outro lado, o origenismo havia chegado à Galiza pela mão dos dois Avitos, um vindo de Jerusalém, o outro de Roma (leitor de Mário Victorino), pensando a impossibilidade da alma ser a partir do nada, raciocinando a exemplo da vontade também necessitada de um

objectivo e denso; um bispo católico frente a um crítico da hierarquia. Por detrás da doutrina da Graça, em Agostinho, temos também a noção de uma graça criada ligada à sacramentalidade eclesial e eclesiástica; enquanto Orígenes pensa a salvação sem predestinação Agostinho introduz a predestinação que anula o universalismo (cf. H. Küng, Os Grandes Pensadores do Cristianismo, trad. (Lisboa 1999) 72-73 e 86-90).

${ }^{4 \wedge}$ L.A. Cerqueira, «A filosofia medieval como fonte da filosofia brasileira», Ágora

1 (jul-dez. 2001) 172.

47 J.P. Klubertanz, «Filosofia nos Estados Unidos da América», Revista Portuguesa de Filosofia 17 ( 1961 ) 296.

48 M. Simonetti, «Priscillian - Priscillianism» in A. Di Berardino (ed.), Encyclopedia of the Early Church, trad. (Cambridge 1992) 711-12. 
substrato (PL 31, 1213-14) $)^{49}$. Quanto ao pelagianismo, possibilitava uma antropologia da liberdade com extensões políticas deletérias para a men sagem cristã ${ }^{50}$.

Orósio pertencia então à diocese de Braga (conforme o teste munho do seu bispo, Avito de Braga, na carta que endereça a Palcónio: PL 41, 805-7), e durante o Inverno de 414-415, provavelmente junto de Agostinho e a pedido deste, inicia a redacção de uma obra que irá gozar de um prestígio enorme inclusive durante a Idade Moderna europeia, a História Contra Os Pagãos:

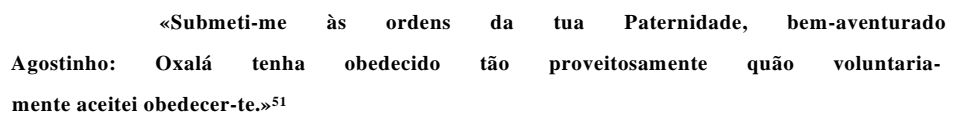

Menos conhecida, mas nem por isso menos interessante, a redacção de uma outra obra $\boldsymbol{O}$ Livro Apologético contra Pelágio. Oriundo das ilhas britânicas, Pelágio (nascido circa 354) rejeitava a predestinação maniqueísta contrapondo-lhe o merecimento de uma vida vivida na observância dos preceitos divinos integralmente radicada na liberdade inata na natureza. Preconizava, por isso, em nome da universalidade de uma imitatio Christi, uma ascese universal, não restrita aos conventos. Todavia, graças à intervenção dos seus censores, a polémica derivou para o campo da discussão sobre o mérito do livre arbítrio, a natureza da Graça divina e o valor dos sacramentos. A questão não era tanto a da afirmação da liberdade, mas a do modo de a concebermos e respectivas consequên cias. Em qualquer caso, recusava-se o nascimento da humanidade no pecado, o que retirava valor à redenção cristã e afastava a necessidade do baptismo das crianças. Se em relação à liberdade, a Graça consistia numa intervenção externa, a liberdade seria implantada no Homem no momento da criação, à semelhança de uma raiz cujos frutos são posteriormente determinados pelas opções feitas.

A explicação para o sucesso editorial dos sete livros que com põem a História do presbítero Orósio é fácil: para além da autoridade que

49 Sobre a complexidade do chamado 'origenismo' vd. H. Crouzel, «Origenism» in

A. Di Berardino (ed.), Encyclopedia... 623-24.

50 Cf. V. Grossi, «Pelagius - Pelagians - Pelagianism» A. Di Berardino (ed.),

Encyclopedia... 665-66.

51 Cf. HCP Livro I, Prólogo p. 21: Paulo Orósio. Historia Contra os Pagaos (Esboço duma Historia da Antiguidade Oriental e Clássica), trad, de J. Cardoso (Braga 1986); Oróse. Histoires (Contre les Païens), texte établi et traduit par M.-P. Amaud-Lindet (Paris 1990). 
lhes conferiu a ficção quase plausível de se tratar de um discípulo de Agostinho, diferentemente d'A Cidade de Deus, trabalho especulativo que visava dar uma interpretação do mundo temporal na sua relação com a eternidade, a História tinha um recorte bem mais simples, mundano. Lembrava Agostinho, em resposta à acusação de culpa já referida, que a história de Roma sempre esteve repleta de misérias, de infortúnios e que, por isso, com uma adequada informação historiográfica, rapidamente se teria de concluir que o terrível acontecimento de 410 era apenas um de muitos males que sempre afligiram a humanidade. Mais ainda. $\mathrm{O}$ seu olhar universalista atento quer à história dos bárbaros quer à dos romanos, o seu apreço pela tradição oral e pelas fontes, o seu interesse e ensaio de explicação da história por aquilo que nela há de mais cruel, a sua crença no império e a sua defesa da autoridade monárquica numa ligação da Igreja com o poder temporal, todas estas características conferir-lhe-ão um tom familiar aos seus futuros leitores. Acresciam, além disso, três notas estruturantes muito bem recebidas - a crença na Providência actuando na História; a justificação dos males baseada no teologuema do pecado; o pessimismo vincado na descrição desses males (misera Roma) - e uma versão alternativa da sucessão dos quatro impérios (translatio imperii), de acordo com a profecia de Daniel (2, 31sg e 7,3sg), como modelos históricos sucessivos: babilónio, macedónio, cartaginês e romano (HCP II 1, p . 89) $)^{52}$.

Orósio não era um nativo romano $\mathrm{e}$ por isso não tinha de defender o mito da cidade eterna ${ }^{53}$. Além disso, as recordações dos combates sangrentos da sua pátria espanhola e o jugo cruel que os roma nos lhe impunham estaria forçosamente no seu espírito. Podia mesmo interrogar-se se a ameaça dos bárbaros era de facto pior do que aquela que a pax romana constituía para as províncias. A sua apologia era assim diri gida contra os pagãos (também romanos) e não contra os bárbaros (muitos deles já cristãos), cuja moderação lhes não é regateada:

«Estes a quem esteve sujeita e à sua mercê toda a terra, puderam tomar quanta terra lhes aprouvesse. Todavia, entregaram-se a si pró-

52 Agostinho, C/v. Dei XVIII, 2 e ibid. XX, 23: Assírio (Babilónico), Persa (Medo), Macedónio (Grego) e Romano, remetendo para o Comentário de S. Jerónimo a Daniel.

53 H. Günther, Le temps de l'histoire. Expérience du monde et catégories temporelles en philosophie de l'histoire de saint Augustin à Pétrarque de Dante à Rousseau, trad. (Paris 1996) 39; P.F. Alberto., «Orósio e Constantino ('hist.' 7, 28)», Classica 22 (1997)133-59.

\section{Faculdade de Letras i Universidade de Coimbra}


prios à guarda e vigilância do poder de Roma - os únicos a quem os reinos

invencíveis temeram.» (HCP I 16, p. 54).

Dos sete Livros que integram a obra interessa-nos o último (embora se deva atentar que na base da sua confecção está a geografia) ${ }^{54}$. O Livro VII, o mais longo e determinante, versa os acontecimentos da era Cristã e constitui-se como um investimento nacionalista consentido. Isto possibilita que a obra seja lida como intermediária na historiografia peninsular, entre o universalismo cristão e imperial de Prudêncio e o nacionalismo consciente de Santo Isidoro de Sevilha num ambiente cultu ral de romanidade ${ }^{55}$. Salta à vista de facto que a obra fecha enunciando o plano de Ataúlfo substituir a România pela Gótia:

«almejava profundamente fazer de todo o Império Romano um só

Império dos Godos» (HCP VII 43, p. 452).

E se este plano não pôde ser realizado integralmente, não obstante o declínio de Roma, a opção de Segerico e depois Vália, os sucessores eleitos de Ataúlfo, pela pax, representava já afinal a consciência clara da irrupção de novos povos na his tória do extremo ocidental da Europa:

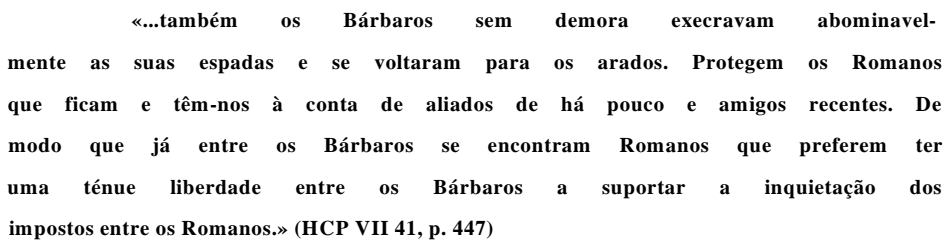

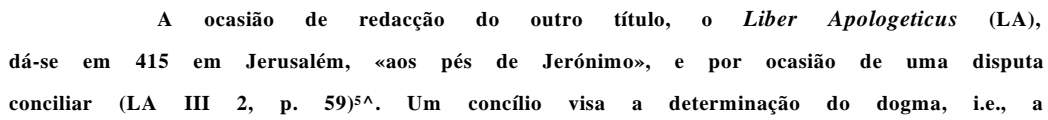

540 primeiro livro é uma introducão sobretudo geográfica; 0 segundo narra a história da Pérsia e da Grécia até ao século V; 0 Livro III sobre a história de Grécia e de Roma até à partilha do Império de Alexandre; 0 IV até à destruição de Cartago pelos Romanos (146); $0 \mathrm{~V}$ até ao fim da guerra civil, i.e., de 146 a 70 a.C.; 0 VI até ao nascimento de Cristo.

55 E. Rivera de Ventosa, «A los orígenes del pensamiento medieval español sobre la Historia: Prudencio, Orosio, San Isidoro», Revista Española de Filosofía Medieval 4 (1997)7-22.

${ }^{5 \wedge} \mathrm{Cf}$. Orósio de Braga. O Livro Apologético contra Pelágio 'Da liberdade do alvedrio '. Texto bilingue, introd., trad., comentario e notas de J.C. de Miranda (Braga 1999). 
mente derivadas. E é precisamente aqui, enfrentando estas expresssões derivadas, que se levanta a intervenção de Orósio. Se procurava seguir Agostinho na definição dogmática da catolicidade ocidental, evidenciava a presença, nesta região onde o Mar começa e a Terra acaba, de expres sões culturais marginais, interpretações regionais do Cristianismo, memó rias dos elementos confundidos numa antropologia exaltadora do livre arbítrio e que, por esse facto, pensava a intervenção de Deus na história e no mundo de uma forma endógena, eventualmente não-cristã. $O$ antídoto contra o pelagianismo passava por repetir Agostinho. Mas tê-lo-á feito Orósio? Deparámo-nos, no fim de contas, com um historiador mais rea lista, alguém que tem mais em conta o mundo do que Agostinho. Esta sua opção de inscrever o tempo no mundo não seria afinal uma marca mais deste particularismo regional?

\section{Martinho de Braga}

Também para o nosso segundo caso, Martinho de Braga, não necessitamos de abandonar a geografia galaico-portuguesa, embora os itinerários, agora, nos possam conduzir até à longínqua Panónia ou desta vez à própria Roma com uma eventual ligação de futuro ao norte inglês onde iremos encontrar, sem que disso pudéssemos esperar, os monges que sob a batuta de Carlos Magno possibilitaram a renascença das letras gre gas em solo latino. De facto, o que ressalta é o conhecimento da interven ção do bispo de Dume feita no século VI por quem há-de assessorar o imperador romano, no século IX. Continuamos também entre os bárbaros, desta feita mesmo no centro da corte sueva ariana, deparando-nos com um relato de heresias e superstições a evitar (De correctione rusticorum), no caso de também os ibéricos do noroeste quererem ingressar na cultura do império, agora no século VI ainda mais cristã, mas sobretudo com uma Formula Vitae Honestae de económico recorte estoico, mormente senequista $^{57}$.

É autor desses dois livros, entre outros mais, Martinho (c. 518579), personagem cuja naturalidade ainda hoje é discutida, mas que pode ser tanto húngara como descendente desse povo suevo em migração

57 P.F. Alberto, «O 'De Ira' de Martinho de Braga. Estudo, edição crítica, trad, e comentário» Mediaevalia. Textos e Estudos 4 (1993) 48-50; Martinho de Braga. Instrução Pastoral sobre Superstições Populares (De Correctione Rusticorum). Edição, tradução, introdução e comentários de A. A. Nascimento (Lisboa 1997); São Martinho de Braga. Opúsculos Morais. Introdução e tradução de $M^{\text {a }}$ de L.S. Ganho et al. (Lisboa 1998); M.L. Colish., The Stoic Tradition. From Antiquity to the Early Middle Ages. II: Stoicism in Christian Latin Thought through the Sixth Century (Leiden New York 1990) 297-301. 
romana (translatio hominum). O certo é que descobrimos nas suas obras uma formação clássica de evidente recorte romano (Séneca, Boécio e Cassiodoro), mas ao mesmo tempo uma intenção clara de trazer o Oriente para o Ocidente (em particular quer pela sua actividade de tradução de 108 sentenças dos Padres do Egipto com vista à educação monástica, Sententiae Patrum Aegyptiorum, quer pelo impulso que deu à mesma actividade, pelo monge Pascásio, dos 358 apotegmas, Vitae Patrum). Dele já se disse tratar-se do «último traço de união entre a patrística grega, ainda viva, e a média latinidade, que vai começar a viver.» ${ }^{58}$. Trata-se, nestes casos, de colecções gregas de ditos de Padres (Paterika), sejam de carácter anedótico sejam reflexo das suas experiências espirituais do deserto (da autoria de Jerónimo, Rufino, Cassiano, Paládio, Teodoreto, etc.), os quais, entre muitas mais línguas, foram traduzidos para latim. José Geraldes Freire editou a tradução de Pascásio e descobriu uma colecção latina, datável do século VI, o que demonstra bem a difusão do género apotegmático na Hispânia ${ }^{59}$. Ora, no século IV, na Síria e no Egipto, o monaquismo era interpretado como uma filosofia cristã, o que representava um entendimento da perfeição cristã nos termos de «uma prática heroica dos conselhos evangélicos e a imitação da vida de Cristo, retirando-se para o deserto e levando uma vida totalmente dedicada a uma rigorosa ascese e à meditação» ${ }^{60}$, i.e., uma vida conforme à natureza e à razão.

Dume, na região de Braga (Bracara), e a sua 'escola' monacal aparecem-nos assim como «ponto de encontro do Oriente e do Ocidente» no século VI ibérico, isto é, suévico-bizantino ${ }^{61}$. Mas o facto é que, tendo ele eventualmente arribado à Península pela cidade do Porto (Portus Galliciae), burgo suevo que possuía uma basílica dedicada a Martinho de Tours (Cedofeita) e uma comunidade céltica cristã de bretões emigrados, a sua obra, nomeadamente a Formula, teria facilmente passado para os 'Scoti'. Estes, por sua vez, tê-la-iam levado à Europa central (um dos

\footnotetext{
${ }^{c 0}$ L.R. Soares, A Linhagem Cultural de S. Martinho de Dume e outros Estudos
} Dumienses (Lisboa 1997) 251. Vd. também P.G.A.de Sousa, Patrología... 85-127.

59 J.G. Freire, A versão latina por Pascásio de Dume dos Apothegmata Patrum, 2 vols. (Coimbra 1971); Id, 'Commonitiones Sanctorum Patrum' Uma nova colecção de Apotegmas (Coimbra 1974).

60 P. Hadot, Qu'est-ce que... 362.

6* P. Gomes, Historia da Filosofia Portuguesa 2. A Patrología Lusitana (Porto 1983) 204; A. do Espírito Santo, «Braga: um centro de cultura no Ocidente Hispânico do séc. VI», Classical2 (1997) 121-32. 
manuscritos, do século X, é proveniente da Abadia de Lorch), conforme o atesta a apresentação do autor de Dume que aí se lê como 'scotus' ou 'scotigena'62 *. Deste ponto de vista Dume é um anti-Vivarium, este uma ilha cultural insensível às mudanças culturais do seu tempo e espaço, aquela uma fusão actualizada entre monaquismo, cultura romano-cristã e germanismo bárbaro.

$$
\text { Martinho de Tours (316/17-397) seria conterrâneo do seu }
$$

homónimo de Braga. Talvez comprometido em acções secretas anti-arianas e tendo experimentado uma vida de anacoreta e de ascetismo, a sua acção missionária desenvolveu-se sobretudo no Loire. Contudo, a sua influência fez-se sobretudo sentir numa forma de monasticismo galoromano fortemente influenciado pela ascese, misticismo e taumaturgia egípcia. Facto relevante, São Bento consagrou-lhe uma capela no local do templo pagão no sopé do Monte Cassino. Ora, segundo o testemunho de Gregorio de Tours, Martinho de Braga teria chegado à Galiza, talvez por instigação do imperador Justiniano (482-565) - o mesmo que mandou encerrar a Academia ateniense (529) e de quem dependerá a futura constituiçãodo Corpus Iuris Civilis - quando as relíquias de Martinho de Tours foram transladadas para Orense, coincidência milagrosa que levou à cura do filho do rei Suevo Carrarico. Em agradecimento o rei abandona a sua fé ariana e entrega Dume a Martinho. Nesse mesmo século VI, mais a leste, em Alexandria, o gramático cristão João Filópono escrevia, em grego, contra Aristóteles, contra Simplicio, contra Proclo, numa enverga dura teórica que o Ocidente ainda não saberia copiar.

O arianismo foi uma heresia que levou ao extremo a tese de Orígenes (+ 254), para quem as três hipóstases da Trindade se distin guiam entre si de forma subordinada embora participando numa única natureza divina. Ario (n. c. 260) acentuou o subordinacionismo, conside rando o Pai como uma mónada absolutamente transcendente ao Filho, por isso, distinto, inferior, apesar de divino também, todavia de diferente natureza e hipóstase ${ }^{\wedge 2}$. Embora o Credo de Niceia lhe tivesse replicado mediante a consagração da doutrina do homoousios, aquela heresia sub sistiu muito para além da data da realização do concílio, 325. O avanço dos Godos promoveu-a ainda mais, presumivelmente até à acção martinusina no século VI.

${ }^{62}$ L.R. Soares, A Linhagem... 59, 242-43.

$\wedge$ Cf. M. Simonetti, «Arius - Arians - Arianism», in A. Di Berardino (ed.), Encyclopedia... 76-78. 
Temos assim também um conversor de arianos, uma persona gem que se distingue na cristianização dos suevos em virtude dos seus resíduos de paganismo, feitos folclore, falta de instrução (De correctione rusticorum). Este título é uma carta dirigida a Polémio, bispo de Astorga com a intenção catequética de correcção dos desvios morais e religiosos dos Homens cuja história é cadenciada por um ritmo triádico: o esqueci mento do Criador e a prática das más acções; o abandono do Criador com os consequentes desvios cultuais, «num deslize acentuado que vai da ado ração ritual à concepção metafísico-teológica, em que a criatura se toma independente e acaba por se considerar autora de si própria» ${ }^{64}$; a substituição do naturalismo pelo antropomorfismo das figuras míticas, provocada uma vez mais pelo demónio. Daqui a fenomenologia das expressões religiosas que tanto podem ser locais como também romanas, mormente o culto aos elementos (Sol, estrelas, fogo, águas, etc.) e os cultos antropomórficos mais ligados à Terra (montes sagrados, culto das árvores, bosques, jardins e campos impersonificados em personagens do panteão como Ceres, Cupido, Diana, Fauno, Silvano, Vénus, etc. ${ }^{65}$.

Para a nossa cultura lusitana é significativa a passagem em que Martinho alude à designação dos epónimos dos dias da semana:



Um pouquinho mais distante deste cenário, Martinho dedica a sua Formula ao rei Miro e um senequista De ira ao bispo Witimer de Orense, neste seguindo Cassiano ao propor a humildade e a auto-disciplina na raiz da espiritualidade cristã $\{$ De Superbia e Exhortatio

\section{A.A. Nascimento., «Introdução» 55. \\ 65 Cf. A.A. Nascimento, «Intr odução» 55-73.}

Faculdade de Letras | Universidade de Coimbra 
Humilitatis). No primeiro destes títulos (FVH 1, p.29) Martinho diz não querer ensinar as práticas árduas dos perfeitos, mas contentar-se com a lei da medida ou equilíbrio (medietas), «sem os preceitos das Divinas Escri turas», advertir «aquilo que pode ser cumprido, mesmo por leigos que vivam recta e virtuosamente, de acordo com a lei natural da razão (huma nae intellegentiae lege)». De facto, o destinatário é o Homem comum e é para ele que se recolhe a homofonia greco-romana de uma vida virtuosa (honesta uita), ou seja, se prescrevem as quatro virtudes seguintes: pru dência, magnanimidade, temperança (continentia) e justiça.

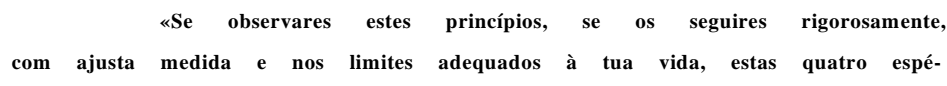
cies de virtude far-te-ão um homem perfeito.» (FVH 6, p. 41).

E inevitável não pensarmos uma vez mais no pelagianismo, isto sem sequer contestarmos a ortodoxia católica de Martinho ${ }^{66}$. Como não podia deixar de ser, a adopção de uma ética da ecúmena ou do uni versal é compatível com a observância do local e do regional, pois o res peito das regras equivale à tomada de consideração de «o tempo, o lugar, as pessoas e as causas da mediania» (FVH 10, p. 43). Não será possível, naturalmente, exagerarmos a componente sistemática. Como em Séneca, interessava-lhes mais a influências das pessoas do que a das doutrinas, e a teologia predominante será a moral em detrimento da especulativa. A consciência do sentimento da fragilidades das coisas humanas confere a este modo de pensar ibérico seminal um horizonte universalista onde razão e equilíbrio serão sempre difíceis tarefas morais a conquistar. Alter nativamente a Agostinho, Martinho aponta para a formação do cristão não mediante um profundo conhecimento da cultura do seu tempo, mas antes da atenção à variedade (ortodoxia/heterodoxia) da cultura cristã.

\section{III - Estradas que conduzem a Ocidente}

No Oriente pensaram Alkindi, Alfarabi e Avicena; no Oci dente, Avempace, Ibn Tufail e Averróis. Quando substituímos a perspec tiva geográfica pela «histórica», mais oficial ou preponderante, a narrativa liga Alfarabi, Avempace e Averróis. 


\section{Mário Santiago de Carvalho}

A resistência de Algazel (+ 1111) à filosofia (falsafa) é habi tualmente interpretada como uma oposição à produção teórica de pelos menos dois dos seus predecessores mais imponentes, Alfarabi (+ 950) e Avicena $(+1037)^{67}$. Mas Avicena inflectiu o pensar de Alfarabi numa direcção que Algazel apenas se limitou a continuar, propondo-se depois mostrar como os dois autores se contradizem ao interpretar Aristóteles ${ }^{68}$. Primeiro, Avicena sobrepõe a dualidade onto-cosmológica (mundo supralunar vs. infra-lunar, alma vs. corpo) à proposta de Alfarabi sobre a uni dade, harmonia e coordenação dos elementos do sistema. Em segundo lugar, o fluxo da emanação é pensado não em díades, mas em tríades (das inteligências celestes surgem entendimento, alma e corpos celestes). A isto corresponde a tríade emanativa com a qual se supera a distinção de Alfarabi entre ser necessário e ser possível: ser necessário por si (Deus); necessário por si e possível por outro (o mundo); possível ou contingente por si (os seres acidentais). Em quarto lugar, enquanto Alfarabi é o filó sofo do intelecto, Avicena é-o da alma (assim distinta do corpo). Por último, adoptando a vertente gnoseológica da teoria da felicidade de Alfa rabi, Avicena concebe-a como libertação do corpo, união às almas dos corpos celestes, para que com estes possa disfrutar da contemplação da Verdade primeira. Poder-se-ia acrescentar que o prestígio da contribuição de Avicena se ficou a dever ao menos aos seguintes factores: a inteligente combinação de aristotelismo e neoplatonismo, a consistente integração do Islão na filosofía, o apuramento da terminologia técnica. Longe de dar mos por resolvida a problemática filosofia oriental/ocidental em Avicena, a solução deste encena uma racionalidade que poderia ser encarada como alternativa à chamada visão dualista ou inter-cultural do logos. Preconi zando «uma nova linguagem da razão» Michel Fattal discriminava as dimensões sincrética ou englobante (Heraclito, estoicismo, São João e São Marcos) e outra analítica ou crítica (Parménides, Platão, Aristóteles, o logos diairético) ${ }^{69}$ para as superar por uma visão «intracultural» do logos em que aquelas duas dimensões se descortinam no interior das obras de um mesmo autor. O tema da contingência, atrevemo-nos a dizê-lo, ilustra esta interpretação.

\footnotetext{
67 Al-Ghazali. Tahafut al-Falasifa. Ed. M. Bouyges (Beirute 21962).

68 M. A. Yabri, El legado... 133, 270, e 141-51.

69 M. Fattal, Pour un nouveau langage de la raison. Convergences entre l'Orient et l'Occident (Paris 1987).
}

Faculdade de Letras | Universidade de Coimbra 


\section{Contingência}

O principal contributo de Avicena consistiu, como dissemos, em prolongar a intuição de Alfarabi (distinção essência/existência e aná lise possível/necessário no seio da ideia de ser) e assim ultrapassá-la. Ao dizer (Liber de phil. prima $I_{2}$ ) que o objecto próprio da metafísica é o ser enquanto ser é patente que a sua leitura deste passo tão aristotélico é cha mada a pensar um criacionismo estranho ao Estagirita (ibid. VI 3) ${ }^{70}$. São sobretudo três as noções aprióricas, antepredicativas, da metafísica: coisa (res/xay), ser (ens/mawjud) e necessário (necesse/daruru), noções que se imprimem na alma por uma primeira impressão directa e interior da reali dade. Captadas pela alma, as noções de 'ente' e 'coisa', v.g., distinguemse entre si, não obstante a sua necessária concomitância; quer dizer: nada há exterior ao ser, porque se algo não existe ao menos tem um ser na inteligência, nomeadamente o ser próprio (essentia) do que é. No princí pio da Lógica, Avicena falava de três estados da essência: no singular (in rebus), no universal (in intellectu) e no em-si que é anterior àquelas duas relações e as fundamenta; pensa-se, v.g., à maneira platónica, na 'equinidade', a natureza absoluta do cavalo, anterior portanto quer a um cavalo quer ao seu conteúdo intelectivo. Esta é, pelo menos, a interpretação mais consagrada, por exemplo por Tomás de Aquino (qdl 8, q. 1, a. I) ${ }^{71}$. No âmbito da dialéctica necessário/possível, Avicena distinguirá aquele género de seres que em si mesmos considerados não têm uma existência necessária (os possíveis) e o género dos necessários. Esta é deveras uma extensão criacionista que assenta na experiência de que no seio do ente finito há entes que recebem o existir de outros e não de si mesmos. O necessário em-si (necesse esse per se) não carece de fundamento, é causa da sua própria existência, é absoluto, imutável, único (ibid. I 6). Uma única existência necessária é a única essência sem quididade, e esta vehementia essendi é também verdade e inteligiblidade supremas (pleni tude onto-noético-lógica). Quanto ao possível em-si (possibile esse per se), a própria possibilidade, por definição ou análise, enfim, cabe-lhe o poder existir; isto só acontece por outrem, o que lhe confere um certo grau de necessidade, necesse esse per alio. Segue-se que a existência é uma concomitância no plano do ser e, por isso, uma certa falsidade, acidentalidade, extrinsecidade. Deparamos-nos com a reinvenção do idea- * 7

$7^{7 \wedge}$ Cf. Avicenna Latinus. Liber de Philosophia Prima sive Scientia Divina. Ed.

critique de la trad, latine médiévale S.V. Riet 2 vols. (Louvain Leiden 1977).

${ }^{7 \wedge}$ Em português, vd. também Tomás de Aquino, O Ente e a Essência. Trad, de M.S.de Carvalho (Porto 1995)

Faculdade de Letras i Universidade de Coimbra 


\section{Mário Santiago de Carvalho}

lismo, pois que o verdadeiro conhecimento será sempre o conhecimento da realidade das coisas e não o das coisas onticamente ditas, estas, por sua vez, só fundamentáveis na plenitude ontológica do ser necessário e pri meiro. Eis a instauração de uma «contingência essencial», na etiqueta antiga mas perfeita de Louis Gardet ${ }^{72}$, porquanto o «mestre da Aurora», nome de Deus no Alcorão, resplandece na manhã do ser, na manhã da criação, pela dom do ser que é o próprio resplendor da inteligência. Pen sar é criar; criar é pensar, será esta a magnífica recepção islâmica do neo platonismo, não sem decisiva influência harranista. Por isso houve quem encontrasse a moderna acepção da existência só no momento em que a ontologia grega é totalmente transformada à luz de uma captação auténti camente metafísica da criação, conquista que não pode ser assacada a Agostinho ou à Patrística Grega, mas à radical diferença entre existência necessária e existênca contingente: «O antigo contraste platónico entre Ser e Devir, entre o eterno e o perecível (ou em termos aristotélicos, entre necessário e contingente) foi sujeito a uma tal reformulação que o ser contingente do mundo criado (originalmente presente apenas como uma 'possibilidade' na mente divina), a propriedade da 'existência real', emerge como um novo atributo ou 'acidente', como uma espécie de bene fício conferido por Deus aos seres possíveis no acto da criação. A novi dade aqui é a noção de uma contingência radical, não apenas a velha ideia aristotélica segundo a qual muitas coisas podiam ser diferentes do que são - que muitos acontecimentos poderiam dar-se de outra maneira - mas que todas as coisas criadas podiam não ter sido criadas, ou seja, que podiam não ter existido.» ${ }^{73}$

\section{Incoerência}

$\mathrm{Na}$ doutrina da possibilidade que passámos em revista Algazel via uma reifícação indevida, por outras palavras, uma indesculpável con fusão entre conceitos e coisas. Para a combater seria preciso reduzir as categorias modais (realidade, necessidade, possibilidade) a seres de razão e destruir o próprio núcleo das relações causais, antecipando assim a conhecida crítica de David Hume. Numa palavra só: seria preciso recons truir uma outra metafísica. Se «possível» ou «necessário» são maneiras de o espírito pensar as coisas (pensando-as como não-existentes e não

72 L. Gardet., La Pensée religieuse d'Aviceme (Ihn Sina) (Paris 1951) 57-61.

73 Ch.H. Kahn., «Why Existence does not emerge as a distinct Concpet in Greek Philosophy» in P. Morewedge (ed.), Philosophy of Existence Ancient and Medieval (New York 1982)7-8.

Faculdade de Letras i Universidade de Coimbra 
podendo pensá-las como não-existentes, respectivamente), também a pro posição 'A é causa de B' apenas traduz a verificação sintética de uma sucessão temporal, B segue-se a A. Em consequência, não será possível provar a existência de Deus. Os argumentos apresentados pelos filósofos nessa direcção não só admitiam uma inferência causal como assumiam a impossibilidade de remontar infinitamente numa série causal e supunham, por fim, a concepção de um Deus improvidente, injusto e antropomórfico. Sócrates, Hipócrates, Platão ou Aristóteles, escreve Algàzel logo no início de Tahafut, são os «maîtres à penser» para os sábios islâmicos presunço sos, que querem destruir a tradição e favorecem a descrença. A defesa algazélica da religião surge motivada pelo preconceito de que a majestosa influência da lógica, da física, da antropologia, da metafísica ou das ciên cias gregas, minava, ou pelo menos subestimava, as leis religiosas e a tradição islâmica. Daí, a exploração do tópico da incoerência, das contra dições em que os filósofos caem, a fim de evidenciar os aspectos positi vos da religião que se vê desgraçada.

Coube a Averróis (+ 1198), ao compor 'ad hominem' uma Incoerência da Incoerência lou A Destruição da Destruição], destruir a metafísica de Algazel e, desse lance, a de Avicena também ${ }^{74}$. De uma forma directa, Averróis acusará Algazel de não ter refutado os filósofos, mas apenas as interpretações de Avicena relativas ao que os filósofos haviam dito. Isto representa uma crítica à atitude de cega submissão à sua própria tradição. É assim que se atém a destruir, uma por uma, as bases do que chamaríamos a filosofia oriental, nalgumas das suas várias relações, a saber: produção e eternidade, finito e infinito, possível e necessário, ema nação ou o problema do uno e do múltiplo, a noção de ciência (ciências divina e humana), causalidade e livre arbítrio. Seguindo Yabri caracteri zamos «filosofia oriental» pelo lugar estrutural da teoria da emanação e pela importância da teoria da alma, além, é claro, do princípio que per mite a ligação entre estes dois domínios, a crença na natureza divina dos corpos celestes, dotados de almas.

Como não podia deixar de ser, Averróis criticará também a contradição intrínseca da noção avicenista, tão nuclear neste como se viu, «possível em si e necessário por outrem». A crítica ao hibridismo põe em causa o ritmo trádico orientalizante. Para o filósofo de Córdova, «entre os caracteres naturais da necessidade não existe nenhum modo de possibili dade», quer dizer, nem o necessário se pode transformar em possível nem

74 Cf. Averroes 'Tahafut Al-tahafut (The Incoherence of the Incoherence). Transi, and introd. by S. Van Den Bergh (London 1978 rep.). 


\section{Mário Santiago de Carvalho}

este em necessário, seja por si seja por outrem. A oposição entre possível e necessário faz daquela invenção avicenista um conceito errado e supérfluo.

Outro tanto dirá Averróis da proposta de harmonização alfarábica. Pôr em relevo a incoerência da incoerência não equivale a ceder a um projecto de harmonização a qualquer preço. Considerando a religião e a filosofia como duas estruturas axiomáticas e hipotético-dedutivas dis tintas, cuja veracidade deve ser buscada no interior de cada uma delas e não fora, Averróis preconizará uma solução de separação, que o dinamar quês latino Boécio de Dácia recuperará, à sua maneira como vimos noutro lugar ${ }^{75}$, e uma tarefa hermenêutica que pode ser lida nos termos de uma «abertura do caminho (...) com vista à emancipação final da razão» ${ }^{76}$. Em vez do diálogo de surdos, propõe Averróis que o filósofo compreenda a religião dentro da religião e o teólogo perceba a filosofia no interior desta. Trata-se, no mesmo lance, de aplicar estratégia hermenêutica idên tica contra alguma da sua própria tradição filosófica islâmica, compreen der Aristóteles dentro de Aristóteles e não com o contágio de ideias neoplatónicas (como sucedia com Avicena). Procedimento equivalente terá desenvolvido o judeu Moisés Maimónides sobretudo no célebre Guia dos Perplexos $^{77}$.

Eis os três princípios fundamentais da teoria hermenêutica averroísta dos textos religiosos: i) todo o discurso religioso, quer no seu sentido literal quer interpretado, é sempre compatível com a razão (a ver dade é una, apenas se distinguindo no modo de enunicação), cabendo à razão transformar os discursos dialécticos e retóricos religiosos em dis cursos demonstrativos; ii) é preciso respeitar a unidade interna de um texto religioso, o que faz com que as interpretações, v.g., do Alcorão devam ser intertextualmente compatíveis; iii) há porém três pilares bási-

75 M.S.de Carvalho, O Problema da Habitação... 193-235.

76 G. Endress \& J.A. Aertsen (ed.), Averroes and the Aristotelian Tradition. Sources, Constitution and Reception of the Philosophy of Ibn Rushd (1126-1198) (Leiden Boston 1999) vii; eventualmente mais acessível, vd. J.M. Ayala Martinez (coord.), Averroes y los averroísmos. Actas del III Congreso Nacional de Filosofía Medieval (Zaragoza 1999).

77 Cf. Mose ben Maimón (Maimonides), Guia de Perplejos (Môrèhnchûkîm). Ed. de D. Gonzalo Maeso (Madrid 1994). Não temos espaço para desenvolver aquí este ponto, mas (e também porque nos encontramos em ano centenário maimonideano) pode ver-se ao menos: R. Hayoun, Maimonide (Paris 1987); O. Leaman, Moses Maimonides (London 1990); contextualização mais ampla em C. Sirat, La filosofia ebraica medievale, trad. (Bolonha 1990); S. Pines \& Y. Yovel (ed.), Maimonides and Philosophy. Papers Presented at the Sixth Jerusalem Philosophical Encounter, Dordrecht 1986; J. Pelaez del Rosal (ed.), Sobre la Vida y Obra de Maimonides. I Congreso Internacional (Córdoba 1991). 
cos da religião que escapam a toda a interpretação: a existência de Deus, a profecia, o Juízo Final.

Estas e todas as outras perspectivas axiomatizantes de inter pretação confluem num princípio só, o de que «interpretar» consiste em trabalhar linguística e hermeneuticamente no quadro do respeito da gra mática da língua e da lógica e demonstração aristotélicas num horizonte de submissão às estruturas axiomáticas dos saberes e, portanto, compatibilizando os discursos religioso e filosófico numa solução não alfarábica. Também «reducere ad concordiam» será a palavra de ordem de Boécio de Dácia $^{78}$. Uma só verdade é buscada nos dois registos e a virtude é a aspiração de ambos, embora a religião as atinja pela conduta prática e a filosofia através do conhecimento. Acima de tudo, ambas têm a sua inde pendência própria, embora sem expressão sociológica. Por outras pala vras, se a verdade é só uma, mas a maneira de a apreender difere, isso deve-se apenas à diferença de inteligência, ao esforço do trabalho inte lectual, ao distinto grau de cultura que separa um sábio de um ser humano vulgar. Também aqui importa não confundir as propostas orientais com as ocidentais, pois, para aquelas, a distinção entre «elite» e «vulgo» assenta em diferentes espécies de conhecimento: um conhecimento gnóstico-ilu minativo, inspirado ou gerado pela união com o Intelecto Agente, parti cularidade exclusiva de um grupo de «iluminados», contra um tipo de conhecimento sensitivo ou intelectual vulgar. Fica todavia explicado por que Boécio de Dácia há-de chamar aos filósofos «sábios deste mundo» ${ }^{9}$ e se a sua expressão sociológica é académica e profissional ela já deixará de o ser no prolongamento de um pensamento «laico» que progressiva mente descobre a filosofia em linguagem vulgar, «nacionalizando-a» geolinguisticamente (casos de Dante ou de Eckhart e.g. em direcções diferentes embora).

Desse horizonte, sem dúvida, a aguda sensibilidade de Averróis para a separação entre religião e filosofía, para a especificidade dos dois discursos, para a dificuldade em se atingir a verdade, para o cuidado na sua transmissão, e estas são as marcas do que em rigor poderíamos desig nar por «racionalismo averroísta», talvez já rasgado por Avempace no cenário da revolução cultural almoada que preconizava o regresso aos princípios e o respeito absoluto pelo princípio do terceiro excluído ${ }^{80}$.

78 Cf. Boécio de Dácia. A Eternidade do Mundo. Trad., introd. e notas de M.S. de Carvalho (Lisboa 1996) 32.

79 Cf. Boécio de Dácia. A Eternidade. . 78.

$80 \quad$ M.A. Yabri, El legado... 267-328.

Faculdade de Letras | Universidade de Coimbra 
Teremos descrito, nós, afinal, neste parágrafo III, duas figuras incomensuráveis? Ou descortinámos figuras atravessadas pela duplici dade intracultural de um logos bifronte? A breve revisitação de Llull afigurou-se-nos como um tertium quid, mas, vale a pena lembrar, personali dades de fronteira como o Maiorquino, marcadas pelo respeito autêntico de uma dada incomensurabilidade, não são insulares. Por falta de espaço limitamo-nos a indicar o modo como Alasdair MacIntyre evoca uma outra destas impressionantes figuras (Tomás de Aquino) que, perante esquemas conceptuais alternativos, conhece e é capaz de falar a linguagem de cada um a partir do seu próprio interior. Amplificamos assim até ao problema da tradição o que noutro lugar designávamos por o «princípio de Tomás» ${ }^{81}$. Enquanto falante nativo de duas línguas-mãe (Agostinho/ Aristóteles) cada uma delas com a sua própria especificidade ele «não precisa de levar a cabo as tarefas de tradução a fim de entender. Antes, porém, na base da sua própria compreensão de ambas as linguagens conceptuais, reconhece os pontos em que a intraduzibilidade apresenta barreiras por cima das quais não se pode descobrir qualquer caminho. Tais pessoas são pouco numerosas. São os 'habitantes' de situações de fronteira que geralmente incorrem na suspeita e na incompreensão dos membros de ambos os partidos opostos.» ${ }^{82}$ Ora, para o problema especí fico que foi aqui o nosso, é sumamente ilustrativo que a surdez de Aristóteles tenha sido curada por quem sabia tanto de Aristóteles.

81 M.S. de Carvalho, «Para um outro modelo de Investigação das Relações entre razão e fé no século XIII», Itinerarium 41 (1995) 42; Id., O Problema da Habitação... 22.

82 A. MacIntyre, Tres versiones... 152. 